\title{
Pengaruh Gaya Kepemimpinan Dan Komitmen Organisasi Terhadap Kepuasan Kerja Serta Dampaknya Terhadap Kinerja Pegawai Pada Kantor Dinas Kependudukan Dan Pencatatan Sipil Kota Jambi
}

\author{
Pantun Bukit $^{1}$, Yunan Surono ${ }^{2}$, Hendro Priono ${ }^{3}$ \\ ${ }^{1,2,3}$ Fakultas Ekonomi Universitas Batanghari Jambi \\ Correspondence email: hendro.priono85@gmail.com
}

\begin{abstract}
The purpose of this research is to find out the description of leadership style, organizational commitment, performance and job satisfaction at the Office of the Office of Population and Civil Registry of Jambi City year 2019. To analyze the influence of leadership style and organizational commitment simultaneously and partially both directly and indirectly to job satisfaction at the Office of the Office of Population and Civil Registry of Jambi City year 2019. To analyze the influence of leadership style and organizational commitment simultaneously and partially both directly and indirectly on performance at the Office of The Office of Population and Civil Registry of Jambi City in 2019 and to analyze the influence of leadership style and employee commitment through job satisfaction to performance at the Office of The Office of Population and Civil Registry of Jambi City year 2019. The population of this study was all employees of the Jambi City Civil Registry and Population Office as many as 95 people. The population has a close relationship with the problems studied. Samples are part of the elements of the population to be examined. In this study, probability sampling techniques were used because the population in this study was not very large. Probability sampling is a sampling technique that provides an opportunity for each member of the population to be selected as a sample member. With probability sampling, it is random or random sampling of the existing population. The sample from this study was all employees of the Jambi City Office of Population and Civil Registry as many as 95 people. The leadership style and commitment of the organization simultaneously has a positive and significant influence on job satisfaction in employees of the Office of Population and Civil Registry of Jambi City. Where the influence of leadership style and simultaneous organizational commitment to job satisfaction simultaneously is worth 40.68\%. Leadership style and organizational commitment through performance can have a direct and indirect effect on job satisfaction. Where the influence of leadership style on job satisfaction through performance is $14.94 \%$, the effect of orgnaization commitment on job satisfaction through performance of $1.82 \%$ and leadership style and organizational commitment together through performance to job satisfaction is $19.97 \%$.
\end{abstract}

Keywords: Commitment Of Organization, Leadership Style, Performance and Satisfaction Through Performance

\section{Pendahuluan}

Kepemimpinan masih menjadi topik yang menarik untuk dikaji dan diteliti, karena paling sering diamati namum merupakan fenomena yang sedikit dipahami. Fenomena gaya kepemimpinan di Indonesia menjadi sebuah masalah menarik dan berpengaruh besar dalam kehidupan politik dan bernegara. Dalam dunia bisnis, gaya kepemimpinan berpengaruh kuat terhadap jalannya organisasi dan kelangsungan hidup organisasi. Peran kepemimpinan sangat strategis dan penting dalam sebuah organisasi sebagai salah satu penentu keberhasilan dalam pencapaian misi, visi dan tujuan organisasi. Maka dari itu, tantangan dalam mengembangkan strategi organisasi yang jelas terutama terletak pada organisasi di satu sisi dan tergantung pada kepemimpinan (Yunarsih, 2009).

Menurut Robbins (2011) kepemimpinan merupakan kemampuan individu untuk memperbaiki, memotivasi dan membuat orang lain mampu memberikan kontribusinya demi efektivitas dan keberhasilan organisasi. Sedangkan menurut Terry (2003) bahwa kepemimpian adalah kegiatan dalam mempengaruhi orang lain untuk bekerja keras dengan penuh kemauan untuk tujuan kelompok. Menurut Stonner (2003) kepemimpinan adalah suatu proses mengarahkan dan mempengaruhi aktivitas yang berkaitan dengan pekerjaan dan anggota kelompok. Pemimpin harus fleksibel dalam pemahaman segala potensi yang dimiliki oleh individu dan berbagai permasalahan yang dihadapai individu tersebut. Dengan melakukan pendekatan tersebut, pemimpin dapat menerapkan segala peraturan dan kebijakan organisasi serta melimpahkan tugas dan tanggung jawab dengan tepat. Hal ini sejalan dengan usaha untuk menumbuhkan komitmen organisasi dari diri pegawai. Pemimpin harus mampu mempengaruhi bawahannya untuk bertindak sesuai dengan visi, misi dan tujuan organisasi. Pemimpin harus mampu memberikan wawasan, membangkitkan kebanggaan serta menumbuhkan sikap hormat dan kepercayaan dari bawahannya.

Komitmen organisasi yang kuat didalam individu akan menyebabkan individu berusaha keras mencapai tujuan organisasi sesuai dengan tujuan kepemimpinan yang sudah direncanakan. Bawahan yang memiliki tingkat komitmen organisasi tinggi akan memiliki pandangan positif dan lebih berusaha berbuat yang terbaik demi kepentingan organisasi. Komitmen yang tinggi menjadikan individu peduli dengan nasib organisasi dan berusaha menjadikan organisasi kearah yang lebih baik, sehingga dengan adanya komitmen yang tinggi kemungkinan 
penurunan kinerja dapat dihindari. Sehingga pemimpin nantinya dapat meningkatkan kinerja pegawai. Kinerja pegawai mengacu pada prestasi kerja pegawai diukur berdasarkan standard atau criteria yang telah ditetapkan perusahaan. Pengelolaan untuk mencapai kinerja pegawai yang sangat tinggi terutama untuk meningkatkan kinerja perusahaan secara keseluruhan. Faktor-faktor yang mempengaruhi kinerja pegawai meliputi strategi organisasi, (nilai tujuan jangka pendek dan jangka panjang, budaya organisasi dan kondisi ekonomi) dan atribut individual antara lain kemampuan dan ketrampilan. Kinerja bisa meningkatkan kepuasan para pegawai dalam organisasi dengan kinerja tinggi daripada organisasi dengan kinerja rendah (Ostroff, 1992). Rivai (2003) mengemukakan kinerja ialah hasil kerja seseorang atau sekelompok orang dalam suatu organisasi sesuai dengan wewenang dan tanggung jawabnya. Lalu Seymor (Cahyono dan Suharto, 2005) menjelaskan bahwa kinerja merupakan tindakan-tindakan atau pelaksanaanpelaksanaan tugas yang dapat diukur atau dinilai. Dengan demikian, kinerja pegawai dalam suatu organisasi perlu diukur atau dinilai, agar dapat diketahui apakah kinerja pegawai itu baik atau buruk.

Kinerja seorang pegawai sangat ditentukan oleh unsur pegawainya, karena itu dalam mengukur kinerja pegawai biasanya diukur dari tampilan kerja pegawainya. Kinerja pegawai yang baik akan berdampak pada kinerja organisasi secara keseluruhan, yang pada akhirnya dapat terlihat dari pencapaian organisasi. Dengan adanya gaya kepemimpinan yang diterapkan oleh pimpinan diharapkan adanya suatu hubungan komunikasi yang harmonis antara pimpinan dan pegawai atau antara pegawai yang satu dengan yang lainnya untuk meningkatkan kinerjanya yang pada akhirnya dapat mempengaruhi kepusan kerja pegawai. Kepuasan kerja merupakan hal yang menjadi perhatian dalam suatuorganisasiperusahaan. Upaya memuaskan pegawai ini penting agar pegawai dapat berkinerja baik,khususunya dalam memberikan layanan kepada nasabah. Studi sebelumnyamemperlihatkan bahwa kepuasan pegawai akan berdampak pada pemberian layanan kepada masyarakat (Diah dan Sunardji, 2005). Mengingat pentingnya kepuasan kerja ini, maka sangat penting bagi organisasi untuk mengetahui faktor-faktor yang berpengaruh terhadap kepuasan kerja pegawai.

Kantor Dinas Kependudukan dan Pencatatan Sipil Kota Jambi merupakan unsur pelaksana Kementerian Dalam Negeri di bidang kependudukan dan pencatatan sipil yang mempunyai tugas merumuskan kebijakan di bidang pendaftaran penduduk, pencatatan sipil, pengelolaan informasi administrasi kependudukan, pemanfaatan database kependudukan dan standar kualifikasi sumber daya manusia pelaksana administrasi kependudukan. Dimana bahwa tunjangan diberikan dalam rangka peningkatan kesejahteraan pegawai negeri sipil daerah dan merupakan bagian penerapan manajemen kerja melalui pengembangan sistem penghargaan atas capaian prestasi kinerja bagi pegawai negeri sipil daerah dilingkungan pemerintah Kota Jambi tugas pokok dan fungsi. Pada Kantor Dinas Kependudukan dan Pencatatan Sipil Kota Jambi dan dari setiap indikator tersebut telah ditetapkan target yang harus tercapai, pada kenyataannya capaian yang dilakukan oleh pegawai belum mencapai kategori sempurna, karena ada beberapa target yang belum tercapai pada tahun tertentu. Hal ini dikarenakan kurangnya tunjangan kinerja daerah dari atasan terhadap pegawai pada tahun yang tidak tercapai targetnya.

Berdasarkan uraian latar belakang, tujuan penelitian ini adalah sebagai berikut ini:

1. Untuk mengetahui gambaran gaya kepemimpinan, komitmen organisasi, kinerja dan kepuasan kerja pada Kantor Dinas Kependudukan dan Pencatatan Sipil Kota Jambi Tahun 2019.

2. Untuk menganalisis pengaruh gaya kepemimpinan dan komitmen organisasi secara langsung maupun tidak langsung terhadap kepuasan kerja pada Kantor Dinas Kependudukan dan Pencatatan Sipil Kota Jambi Tahun 2019.

3. Untuk menganalisis pengaruh gaya kepemimpinan dan komitmen organisasi secara langsung maupun tidak langsung terhadap kinerja pada Kantor Dinas Kependudukan dan Pencatatan Sipil Kota Jambi Tahun 2019.

4. Untuk menganalisis pengaruh kepuasan kerja terhadap kinerja pada Kantor Dinas Kependudukan dan Pencatatan Sipil Kota Jambi Tahun 2019.

5. Untuk menganalisis pengaruh gaya kepemimpinan dan komitmen pegawai melalui kepuasan kerja terhadap kinerja pada Kantor Dinas Kependudukan dan Pencatatan Sipil Kota Jambi Tahun 2019.

\section{Metode}

Sesuai dengan permasalahan yang diuraikan, penelitian ini dilakukan dengan pendekatan kuantitatif. Pendekatan kuantitatif menurut Sugiyono (2016) merupakan penelitian yang banyak dituntut menggunakan angka, mulai dari pengumpulan data, penafsiran terhadap data tersebut serta hasilnya. Menurut Nasution (2008) dalam penelitian kuantitatif peneliti lebih spesifik memusatkan perhatian kepada berbagai aspek-aspek tertentu dan sering menunjukkan hubungan antara berbagai variabel atau memberi gambaran yang jelas tentang situasi yang bersifat deskriptif. Pada penelitian ini objek penelitian adalah Kantor Dinas Kependudukan dan pencatatan Sipil Kota Jambi dengan unit analisisnya adalah semua pegawai Dinas Kependudukan dan pencatatan Sipil Kota Jambi pada tahun 2019, yang berjumlah 95 orang terdiri dari PNS dan PTT, dan tidak termasuk unsur pimpinan. Sampel yang memberikan peluang bagi setiap anggota populasi untuk dipilih menjadi anggota sampel. Dengan probability sampling, maka pengambilan sampel secara acak atau random dari populasi yang ada. Sampel dari penelitian ini adalah seluruh pegawai Kantor Dinas Kependudukan dan Pencatatan Sipil Kota Jambi sebanyak 95 orang. 
Pantun Bukit et al, Pengaruh Gaya Kepemimpinan Dan Komitmen Organisasi Terhadap Kepuasan Kerja Serta Dampaknya Terhadap Kinerja Pegawai Pada Kantor Dinas Kependudukan Dan Pencatatan Sipil Kota Jambi

\section{Hasil}

Tabel 1

Hasil Analisis Deskriptif Per Variabel

\begin{tabular}{|c|c|c|c|c|}
\hline No & Variabel & Total & Rentang Skala & Hasil Hipotesis \\
\hline 1 & Gaya Kepemimpinan & 4.379 & $3990-4750$ & Sangat Baik \\
\hline 2 & Komitmen Organisasi & 3.134 & 2584-3191 & Baik \\
\hline 3 & Kepuasan Kerja & 4.870 & $4788-5700$ & Puas \\
\hline 4 & Kinerja & 5.843 & $4845-5984$ & Sangat Baik \\
\hline
\end{tabular}

Sumber: data olahan

Data Tabel 1, dapat di gambarkan bahwasanya gaya kepemimpinan mendapatkan total skor 4.379 yang berarti sangat baik. Sedangkan pegawai baik terhadap pernyataan pada variabel komitmen organisasi dengan total skor sebesar 3.134. Kepuasan kerja mendapatkan total skor sebesar 4.870 yang artinya pegawai puas dengan hasil yang di dapatkan dari Kantor Dinas Kependudukan dan Pencatatan dan kinerja pegawai pada Kantor Dinas Kependudukan dan Pencatatan Sipil mendapatkan total skor sebesar 5.843 yang artinya baik.

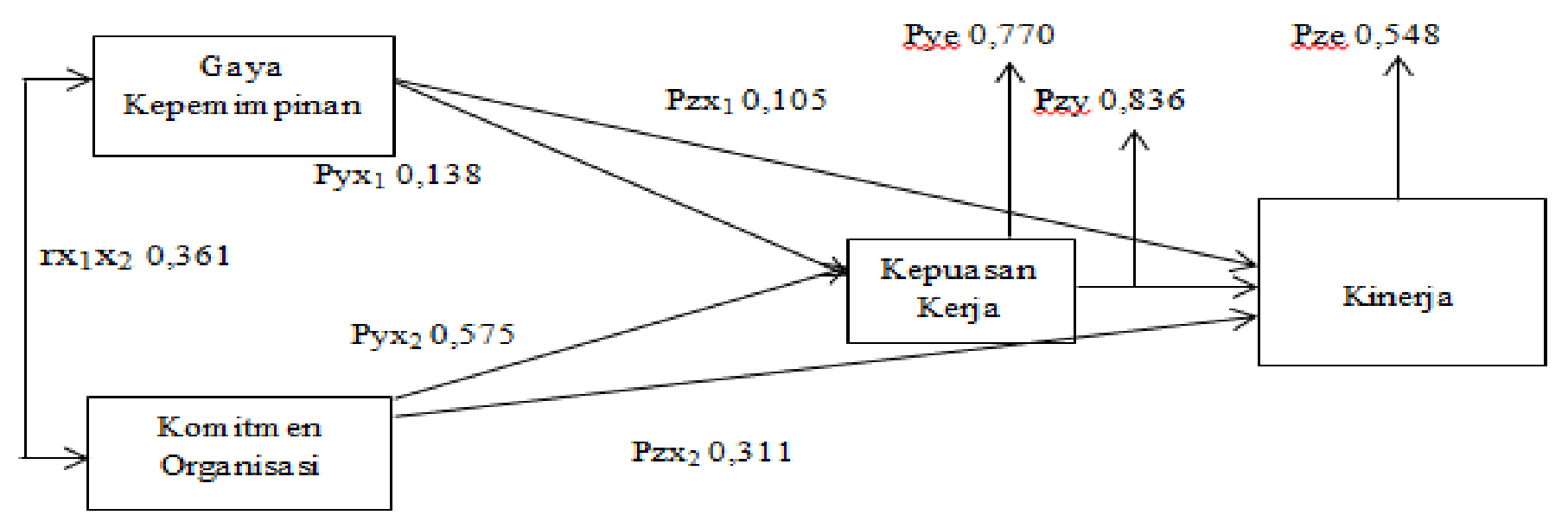

Gambar 1.

Hubungan Kausalitas Analisis Koefisien Jalur Antara Variabel $X_{1}, X_{2}, Y$ dan $Z$

Berdasarkan poin-poin dari setiap variabel maka dapat ditarik kesimpulan bahw kondisi gaya kepempimpinan dan kinerja pada Kantor Dinas Kependudukan dan Pencatatan Sipil sangat baik sehingga hal ini juga didukung oleh komitmen setiap pegawai yang baik sehingga dapat menumbuhkan kepuasan kerja pegawai. Untuk mengetahui pengaruh total antara masing-masing variabel bebas, seperti gaya kepemimpinan $\left(\mathrm{X}_{1}\right)$, komitmen organisasi $\left(\mathrm{X}_{2}\right)$ melalui variabel intervening kinerja (Y) terhadap variabel terikat kepuasan kerja (Z) maka apabila strukutr IV tersebut dijadikan menjadi satu kesatuan utuh dari analisis koefisien jalur (path analysis) yang digunakan dalam penelitian ini, dapat dilihat pada Gambar 1.

\section{Pengaruh Gaya Kepemimpinan dan Komitmen Organisasi Baik Secara Langsung Maupun Tidak Langsung Terhadap Kepuasan Kerja Pegawai Pada Kantor Dinas Kependudukan dan Pencatatan Sipil}

Pengaruh langsung antara gaya kepemimpinan dan komitmen organisasi terhadap kepuasan kerja yaitu sebesar 34,96\% dan pengaruh tidak langsung antara gaya kepemimpinan dan komitmen organisasi secara simultan terhadap kepuasan kerja yaitu sebesar 5,72\%. Total pengaruh langsung dan tidak langsung gaya kepemimpinan dan komitmen organisasi terhadap kepuasan kerja secara simultan yaitu sebesar 40,68\%. Seorang pemimpin mempunyai tanggung jawab untuk melaksanakan tugas serta tanggung jawab yang demikian, dituntut adanya seorang pemimpin yang mengenal secara keseluruhan anggota organisasi sehingga dapat menumbuhkan kerja sama yang harmonis diantara komponen organisasi. Peran pemimpin menjadi sangat penting. dalam keberhasilan organisasi yang dipimpinnya dalam hal arahan, gaya supportif, gaya partisipatif dan gaya orientasi prestasi untuk mencapai kinerja. Hal ini berarti seorang pemimpin yang efektif mempengaruhi para pegawai atau pengikutnya untuk mempunyai optimism yang besar, rasa percaya diri, serta komitmen kepada tujuan dan misi organisasi. Hasil penelitian ini sejalan dengan penelitian yang dilakukan oleh Edi Mardalis (2015) yang menyatakan bahwa gaya kepemimpinan dan komitmen organisasi berpengaruh terhadap kepuasan kerja. 
Pantun Bukit et al, Pengaruh Gaya Kepemimpinan Dan Komitmen Organisasi Terhadap Kepuasan Kerja Serta Dampaknya Terhadap Kinerja Pegawai Pada Kantor Dinas Kependudukan Dan Pencatatan Sipil Kota Jambi

\section{Pengaruh Gaya Kepemimpinan dan Komitmen Organisasi Baik Secara Langsung Maupun Tidak Langsung Terhadap Kinerja Pegawai Pada Kantor Dinas Kependudukan dan Pencatatan Sipil}

Pengaruh langsung antara gaya kepemimpinan dan komitmen organisasi terhadap kinerja yaitu sebesar $10,77 \%$ dan pengaruh tidak langsung antara gaya kepemimpinan dan komitmen organisasi secara simultan terhadap kinerja yaitu sebesar 2,34\%. Total pengaruh langsung dan tidak langsung gaya kepemimpinan dan komitmen organisasi terhadap kinerja secara simultan yaitu sebesar $13,11 \%$. Variabel gaya kepemimpinan dan komitmen organisasi mempunyai peranan yang sangat penting terhadap kinerja karena gaya kepemimpinan yang baik dan sesuai dengan kondisi organisasi, didukung oleh unit manajerial yang berkomitmen dalam mencapai tujuan-tujuan yang telah ditetapkan sangat berdampak positif terhadap peningkatan kinerja. Hasil penelitian ini sejalan dengan penelitian yang dilakukan oleh Tobigo (2016) yang menyatakan bahwa gaya kepemimpinan dan komitmen organisasi dapat mempengaruhi kinerja pegawai.

\section{Pengaruh Kepuasan Kerja Terhadap Kinerja Pegawai Pada Kantor Dinas Kependudukan dan Pencatatan Sipil}

Pengaruh langsung kinerja terhadap kepuasan kerja sebesar 69,88\%, ini menunjukkan bahwa kinerja secara langsung berpengaruh terhadap kepuasan kerja pada Dinas Kependudukan dan Pencatatan Sipil. Hal ini menjelaskan bahwa apabila kinerja pegawai tinggi dalam menjalankan tugas yang ditetapkan, maka akan mampu meningkatkan kepuasan kerja. Hal ini berarti ketika pegawai merasa sangat puas dengan pekerjaannya, gaji, rekan kerja dan lain-lain maka mereka akan melakukan kinerja dengan optimal. Ketika semua aspek kepuasan kerja yang berkaitan dengan pegawai dapat terpenuhi oleh instansi, maka pegawai akan melakukan optimalisasi kerja untuk instansi. Namun, supaya kinerja pegawai tetap bertahan maksimal maka harus dipenuhi aspek-aspek kepuasan kerja yang telah ada saat ini secara terus menerus. Hasil penelitian ini sejalan dengan penelitian yang dilakukan oleh Arianto (2010) yang menyatakan bahwa ada pengaruh langsung antara kepuasan kerja dan kinerja.

\section{Pengaruh Gaya Kepemimpinan dan Komitmen Organisasi Melalui Kepuasan Kerja Terhadap Kinerja Pegawai Pada Kantor Dinas Kependudukan dan Pencatatan Sipil}

Pengaruh langsung antara gaya kepemimpinan terhadap kinerja melalui kepuasan kerja pengaruhnya sebesar $1,21 \%$ dan pengaruh tidak langsung antara gaya kepemimpinan terhadap kinerja melalui komitmen organisasi dan kepuasan kerja sebesar 2,29\% dan total pengaruhnya adalah sebesar 3,50\%. Pengaruh langsung komitmen organisasi terhadap kinerja melalui kepuasan kerja sebesar $14,94 \%$ dan pengaruh tidak langsung antara komitmen organisasi terhadap kinerja melalui gaya kepemimpinan dan kepuasan kerja sebesar 1,82\% dan pengaruh total sebesar $16,76 \%$. Pengaruh langsung antara gaya kepemimpinan dan komitmen organisasi secara simultan terhadap kinerja melalui kepuasan kerja pengaruhnya sebesar $16,15 \%$ dan pengaruh tidak langsung antara gaya kepemimpinan terhadap kinerja melalui kepuasan kerja sebesar 3,64\% dan total antara gaya kepemimpinan dan komitmen organisasi terhadap kinerja melalui kepuasan kerja yaitu sebesar 19,97\%. Hasil penelitian ini menunjukkan hasil yang sama dengan penelitian yang dilakukan oleh Ardianto (2010) yang menunjukkan bahwa kepuasan kerja memberikan pengaruh yang positif dan signifikan terhadap kepuasan kerja dalam mempengaruhi pegawai dalam melaksanakan pekerjaan.

\section{Simpulan}

Berdasarkan hasil analisa data dan pembahasan dalam penelitian ini dapat disimpulkan bahwa gaya kepemimpinan, komitmen organisasi, kinerja dan kepuasan kerja pegawai pada Kantor Dinas Pendudukan dan Pencatatan Sipil dikategori baik dalam pelaksanaan kegiatan yang telah ditetapkan oleh kantor. Gaya kepemimpinan dan komitmen organisasi secara langsung dan tidak langsung memiliki pengaruh positif terhadap kepuasan kerja pada pegawai Kantor Dinas Kependudukan dan Pencatatan Sipil Kota Jambi. Gaya kepemimpinan dan komitmen organisasi secara langsung dan tidak langsung memiliki pengaruh positif terhadap kinerja pegawai pada Kantor Dinas Kependudukan dan Pencatatan Sipil Kota Jambi. Kepuasan kerja memiliki pengaruh langsung terhadap kinerja pegawai pada Kantor Dinas Kependudukan dan Pencatatan Sipil Kota Jambi. Gaya kepemimpinan dan komitmen organisasi melalui kepuasan kerja dapat berpengaruh langsung dan tidak langsung terhadap kinerja., pengaruh komitmen orgnaisasi terhadap kepuasan kerja melalui kinerja dan secara langsung gaya kepemimpinan dan komitmen organisasi melalui kinerja terhadap kepuasan kerja.

\section{Daftar Pustaka}

A.F. Stoner, James, 2006, Manajemen Tenaga Kerja. Erlangga: Jakarta.

Ardianto, 2010, Pengaruh Kompensasi, Supervisi, Beban Kerja dan Kelompok Kerja Terhadap Kinerja Melalui Mediasi Variabel Kepuasan Kerja Pegawai (Studi Kasus pada Pegawai Bagian Produksi PT. FUMIRA). EJurnal Manajemen, Unud Vol.5 No.1.

Edi dan Mardalis, 2015, Pengaruh Gaya Kepemimpinan dan Komitmen Organisasi Terhadap Disiplin Kerja Dengan kepuasan Kerja Sebagai Variabel Intervening. Jurnal Ekonomi Manajemen Sumber Daya Vo.17 No.2. 
Pantun Bukit et al, Pengaruh Gaya Kepemimpinan Dan Komitmen Organisasi Terhadap Kepuasan Kerja Serta Dampaknya Terhadap Kinerja Pegawai Pada Kantor Dinas Kependudukan Dan Pencatatan Sipil Kota Jambi

G.R. Terry George. 2003, Prinsip-prinsip Manajemen. PT. Bumi Aksara:

Jakarta

M. Alhudhori dan Wahyu Aldino, 2017, Pengaruh Kepemimpinan dan Disiplin Terhadap motivasi Kerja Serta Dampaknya Pada Kinerja Pegawai Rumah Sakit Umum Bersaudara Kabupaten Bungo. Jurnal Manajemen dan Sains Vol.2 No.1.

M. Alhudhori dan M. Zahari dkk, 2019, Pengaruh Gaya Kepemimpinan dan Insentif Terhadap Motivasi Serta Dampaknya Terhadap Kinerja Pegawai DInas Peternakan dan Perikanan Kabupaten Bungo. Journal Of Economics and Business Vol.3 No.2.

Tobigo, 2016, pengaruh Gaya Kepemimpinan, Kepuasan Kerja dan Komitmen Organsasi Terhadap Kinerja Pegawai Kantor Camat Witaponda Kabupaten Morowali. Jurnal Katalogis Vol.4 No.12.

Yuniarsih, 2009, Sumber Daya Manusia dan Produktivitas Kerja. Alfabeta: Bandung. 